Review Article

\title{
Preimplantation Exposure to Bisphenol A and Triclosan May Lead to Implantation Failure in Humans
}

\author{
Mu Yuan, ${ }^{1}$ Ming-Zhu Bai, ${ }^{2}$ Xu-Feng Huang, ${ }^{3}$ Yue Zhang, ${ }^{1}$ Jing Liu, \\ Min-Hao Hu, ${ }^{1}$ Wei-Qian Zheng, ${ }^{1}$ and Fan Jin ${ }^{1}$ \\ ${ }^{1}$ Department of Reproductive Endocrinology, Women's Hospital, School of Medicine, Zhejiang University, 1 Xueshi Road, \\ Hangzhou 310006, China \\ ${ }^{2}$ Department of Obstetrics and Gynecology, Shanghai First People's Hospital, Shanghai Jiaotong University, Shanghai 201600, China \\ ${ }^{3}$ School of Medicine, University of Wollongong and Illawarra Health and Medical Research Institute, Wollongong, NSW 2522, Australia
}

Correspondence should be addressed to Fan Jin; jinfan@zju.edu.cn

Received 19 February 2015; Revised 21 June 2015; Accepted 25 June 2015

Academic Editor: Shi-Wen Jiang

Copyright (C) $2015 \mathrm{Mu}$ Yuan et al. This is an open access article distributed under the Creative Commons Attribution License, which permits unrestricted use, distribution, and reproduction in any medium, provided the original work is properly cited.

Endocrine disrupting chemicals (EDCs) are chemicals that have the capacity to interfere with normal endocrine systems. Two EDCs, bisphenol A (BPA) and triclosan (TCS), are mass-produced and widespread. They both have estrogenic properties and similar chemical structures and pharmacokinetic features and have been detected in human fluids and tissues. Clinical evidence has suggested a positive association between BPA exposure and implantation failure in IVF patients. Studies in mouse models have suggested that preimplantation exposure to BPA and TCS can lead to implantation failure. This paper reviews the relationship between preimplantation exposure to BPA and TCS and implantation failure and discusses the remaining problems and possible solutions.

\section{Introduction}

During the last few decades, the incidence of human infertility has significantly increased in many countries, such as the United States and China [1-5]. The rate of this increase is too rapid to be explained by genetic mutations. More than $10 \%$ of infertile couples suffer from infertility of an unexplained nature [6]. The women in these couples have normal ovulatory cycles and hormonal profiles and no organ pathologies. Their partners show no evidence of semen quality problems. In the meantime, the production of many artificial chemicals such as plastics has been increased [7].

Some chemicals which have been widely used for decades have recently been found to have the ability to disrupt endocrine function in humans. They are called endocrine disrupting chemicals (EDCs). Bisphenol A (BPA) and triclosan (TCS) are EDCs with similar chemical structures to $17 \beta$-estradiol [8] (Figure 1). They have recently been noticed due to their ubiquitous presence in the environment and in human fluids and tissues [9-23]. BPA is the monomer used in the production of polycarbonate plastics and some epoxy resins. It is one of the most-produced chemicals worldwide, with over six billion pounds produced each year [21]. TCS is an antimicrobial additive used in many personal care and household products.

Many studies have suggested that BPA exposure is associated with female infertility [15-17]. However, the association between TCS exposure and female infertility remains unknown. Mice have been used as an animal model to study the association between the exposure to these two chemicals and infertility [24-28].

Subtle changes in estrogen levels can lead to implantation failure in humans and mice $[29,30]$. BPA and TCS have estrogenic activity in vitro and in vivo [21,31]. BPA binds to both ER $\alpha$ and ER $\beta$ [32-35]. Both BPA and TCS have many biological effects mediated via estrogen receptors [3639]. Thus, BPA and TCS may cause implantation failure due to their ability to mimic estrogen in humans [40-42]. In human beings, from oocyte maturation to implantation, the biological features of the oocyte and the embryo change 
$17 \beta$-estradiol

Molecular formula: $\mathrm{C} 18 \mathrm{H} 24 \mathrm{O} 2$

BPA

Molecular formula: $\mathrm{C} 15 \mathrm{H} 16 \mathrm{O} 2$

TCS

Molecular formula: $\mathrm{C} 12 \mathrm{H} 7 \mathrm{Cl} 3 \mathrm{O} 2$<smiles>C[C@]12CC[C@H]3c4ccc(O)cc4CC[C@]3([C@@H]1O)[C@@H]2O</smiles>

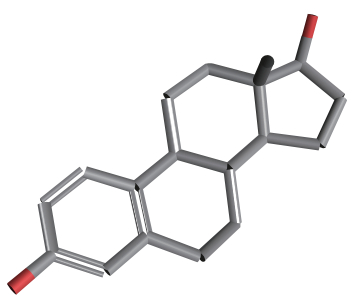

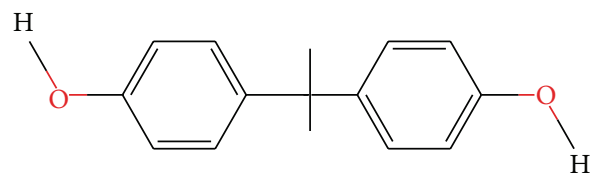<smiles>Oc1cc(Cl)ccc1Oc1ccc(Cl)cc1Cl</smiles>
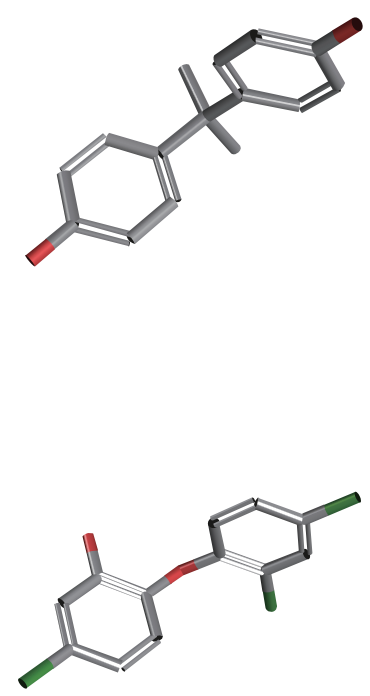

FIGURE 1: Chemical structures of BPA, TCS, and $17 \beta$-estradiol.

dramatically. The levels of sex hormones, such as estrogen, progesterone, and androgen, and their receptors also change dramatically. Thus, the sensitivity of the female reproductive system to BPA and TCS may vary depending on the time of exposure. It has been reported that, in mice, preimplantation exposure to the same amount of BPA or TCS on gestational day $2 / 3$ is more potent to induce embryo implantation failure than exposure on gestational day $0 / 1$ [27, 28]. Thus, in mice, gestational day 2-3 may be a sensitive window for BPA and TCS. Exposure to these two endocrine disruptors during a sensitive window might lead to implantation failure. However, in human beings, the sensitive window for these EDCs still needs further investigation.

\section{Exposure and Detection of BPA and TCS in Humans}

2.1. The Route and Amount of Exposure to BPA and TCS in Humans. There is a trend of increased exposure to endocrine disrupting chemicals, including BPA and TCS. In 2008, it was reported that daily exposure of BPA to humans is below $0.1 \mu \mathrm{g} / \mathrm{kg} /$ day for the majority of the population [43]. In 2011, Taylor et al. suggested that total daily human exposure of BPA is via multiple routes and is much higher than previously assumed based on animal studies and pharmacokinetic features of BPA in human and animal [44]. Recently, Lassen et al. [45] reported that the median daily intake of BPA among 33 Danish men is approximately $27 \mathrm{ng} / \mathrm{kg} /$ day.

Although BPA and TCS can be absorbed orally, dermally, and by inhalation [46], the majority of absorption occurs via ingestion. It is estimated that $90-99 \%$ of BPA exposure in adults and children is from food [47-49]. Allmyr et al. [50] suggested that oral care products are probably the most important means of exposure to TCS in adults because brushing teeth with TCS-containing toothpaste has been shown to result in a large and rapid uptake of TCS. However, the percentage of TCS ingested orally in relation to total TCS absorption is not known. 
TABLE 1: The distribution and amount of BPA and TCS in human tissue.

\begin{tabular}{|c|c|c|c|}
\hline Chemical & Tissue type & Concentration & References \\
\hline \multirow{11}{*}{ BPA } & Serum (adult) & $\sim 1-2 \mathrm{ng} / \mathrm{mL}$ & {$[22,81]$} \\
\hline & Serum (fetal) & $\sim 1-2 \mathrm{ng} / \mathrm{mL}$ & {$[22]$} \\
\hline & Breast milk & $0.61 \pm 0.20 \mathrm{ng} / \mathrm{mL}$ & {$[82]$} \\
\hline & Colostrum & $3.41 \pm 0.13 \mathrm{ng} / \mathrm{mL}$ & {$[83]$} \\
\hline & Follicular fluid & $\sim 1-2 \mathrm{ng} / \mathrm{mL}$ & {$[22]$} \\
\hline & Amniotic fluid (full term) & $\sim 1-2 \mathrm{ng} / \mathrm{mL}$ & {$[22]$} \\
\hline & Amniotic fluid (15-18-week gestation) & $8.3 \pm 8.7 \mathrm{ng} / \mathrm{mL}$ & {$[22]$} \\
\hline & Urine & $2.75-3.3 \mu \mathrm{g} / \mathrm{g}$ creatinine $(\sim 3.00 \mathrm{ng} / \mathrm{mL})$ & {$[84,85]$} \\
\hline & Brain & $0.91 \mathrm{ng} / \mathrm{g}$ & {$[10]$} \\
\hline & Adipose tissue & $3.78-5.83 \mathrm{ng} / \mathrm{g}$ & {$[10,86]$} \\
\hline & Liver & $1.48 \mathrm{ng} / \mathrm{g}$ & {$[10]$} \\
\hline \multirow{5}{*}{ TCS } & Serum & $4.1-19 \mathrm{ng} / \mathrm{g}$ & {$[50]$} \\
\hline & Breast milk & $1.3 \pm 2.7 \mathrm{ng} / \mathrm{g}$ fresh weight & [87] \\
\hline & Urine & $3.55 \mu \mathrm{g} / \mathrm{g}$ creatinine $(3.77 \mathrm{ng} / \mathrm{mL})$ & {$[84]$} \\
\hline & Adipose tissue & $0.61 \mathrm{ng} / \mathrm{g}$ & {$[10]$} \\
\hline & Liver & $3.14 \mathrm{ng} / \mathrm{g}$ & {$[10]$} \\
\hline
\end{tabular}

Rodricks et al. [51] estimated the amount of human daily exposure to TCS from two approaches. One approach is based on the estimation of the combination of daily intake products, and the other is based on biomonitoring data from human volunteers. The total intake of TCS per day from the consumer products evaluated were 0.047, 0.065 , and $0.073 \mathrm{mg} / \mathrm{kg} /$ day for men, women, and children, respectively [51]. The daily TCS intake estimates based on the 50th percentile urinary concentrations of TCS reported in the NHANES (National Health and Nutrition Examination Survey) 2003-2004 were approximately 0.0002, 0.0002, and $0.0001 \mathrm{mg} / \mathrm{kg} / \mathrm{day}$ for men, women, and children, respectively [51]. The estimates based on the 95th percentile urinary concentrations of TCS were approximately $0.009,0.007$, and $0.004 \mathrm{mg} / \mathrm{kg} /$ day [51]. The estimated exposure level of TCS based on biomonitoring data is much higher than the product-based TCS intake estimates and suggests that actual TCS intakes are lower than the product-based estimates.

People living in different regions or having different living habits are probably exposed to different amounts of these two EDCs. And the human exposure level of BPA and TCS remains unclear and needs further investigation.

\subsection{Distribution and Amount of TCS and BPA in Human} Tissue. BPA and TCS have been detected in the blood, breast milk, urine, adipose tissue, liver, and brain of most human volunteers [9-21]. BPA has also been detected in human amniotic fluid and follicular fluid $[22,23]$. The distribution and amount of BPA and TCS in the human body are listed in Table 1. It is interesting that BPA has an $\sim 5$-fold higher concentration at 15-18-week gestation, which must be considered in evaluating the potential for human exposure to BPA [22]. The concentrations of BPA in serum, breast milk, follicular fluid, amniotic fluid (full term), and urine are very close, suggesting that BPA is distributed evenly in human fluids. The distribution and amount of BPA and samples suggest a profile of ubiquitous presentation in human body.

\section{Pharmacokinetics of BPA and TCS}

3.1. BPA. Völkel et al. [52] administered $5 \mathrm{mg}$ radioactive $\mathrm{BPA} /$ person (54-90 ug/kg body weight) and reported that this BPA was completely eliminated from the body within $24 \mathrm{~h}$. Maximum plasma concentrations were reached $80 \mathrm{~min}$ after dosing and rapidly declined for the next $6 \mathrm{~h}$. BPA is only detected in its glucuronidated form and not as free BPA. This study indicates that BPA was absorbed from the gastrointestinal tract quickly, conjugated with glucuronic acid in the liver, and BPA-glucuronide was rapidly filtered from the blood by the kidneys and excreted in the urine [52]. Acute studies in both mice and humans indicate rapid metabolism and clearance of BPA $[44,52,53]$.

3.2. TCS. The absorption of TCS following oral administration in both humans and mice is rapid and efficient [51]. Maximum plasma concentrations were achieved 1 to $3 \mathrm{~h}$ following administration in humans and 1 to $4 \mathrm{~h}$ in mice, respectively $[51,54]$. In humans, TCS does not accumulate in the blood [55]. Nearly all of the TCS absorbed is metabolized to sulfate and glucuronide conjugates in both humans and mice [51, 56, 57]. In humans, about $80-85 \%$ of the administered dose in volunteers is excreted in the urine (71-80\%) or feces (5-7\%) in the form of conjugated metabolite, and the elimination halflife of TCS is estimated to be approximately 10 to $20 \mathrm{~h}[51,54]$. Most of the absorbed TCS can be excreted from the human body less than $24 \mathrm{~h}$ after exposure [54].

In short, the pharmacokinetic features of TCS are very similar to BPA in both humans and mice. In both humans and mice, TCS can be rapidly and nearly completely absorbed, metabolized to glucuronide and sulfate conjugates, and excreted. 


\section{Preimplantation Exposure to BPA and TCS Can Cause Implantation Failure}

Accumulating evidence suggests that there is an association between women's exposure to BPA and female infertility. Moreover, animal model studies have suggested that exposure to BPA, TCS, or both BPA and TCS during the preimplantation period could lead to implantation failure in mice.

4.1. Clinical Studies. In 2005, Sugiura-Ogasawara et al. [17] reported that BPA is associated with recurrent miscarriage in humans. Recently, Ehrlich et al. [15] reported a significant linear dose-response association between increased urinary BPA concentrations and a decreased number of oocytes (overall and mature), a decreased number of normally fertilized oocytes, and decreased peak serum estradiol levels. The mean number of oocytes and normally fertilized oocytes decreased by 24 and $27 \%$, respectively, for the highest versus the lowest quartile of urinary BPA (trend test $P<0.001$ and 0.002 , resp.). Women with urinary BPA above the lowest quartile had decreased blastocyst formation (trend test $P=$ 0.08). Ehrlich et al. [16] also claimed a positive linear doseresponse association between BPA urinary concentrations and implantation failure.

The correlation between the concentration of TCS in pregnant women and female infertility remains unclear due to a lack of investigation. However, the similarity of the distribution, chemical structures, and estrogenic activity of BPA and TCS suggests the possible involvement of TCS in implantation failure.

4.2. Animal Studies. Implantation failure could be caused by the embryo itself, inadequate uterine receptivity, or defects in communication between the embryo and the endometrium. It is generally assumed that the embryo itself is probably only responsible for one-third of IVF failures, and the other twothirds of implantation failures occur due to impaired uterine receptivity or defects in embryo-endometrium communication [58-60]. Animal models have been used to investigate the effect of preimplantation exposure of BPA and TCS on implantation.

Crawford and deCatanzaro [28] studied the impact of preimplantation exposure to BPA, TCS, and BPA and TCS on implantation rates in mice. They found that exposure to TCS on the level of $523 / 785 \mathrm{mg} / \mathrm{kg} /$ day on gestational days (GD) 1-3 could significantly reduce implantation rates by $30 \% / 40 \%$ [28]. They also found that although doses of $4 \mathrm{mg}$ BPA $(122 \mathrm{mg} / \mathrm{kg})$ and $9 \mathrm{mg}$ triclosan $(262 \mathrm{mg} / \mathrm{kg})$ on GD 1-3 were individually ineffective, in combination they reduced the number of implantation sites and also increased gestation length [28]. Xiao et al. [24] showed that preimplantation exposure to $100 \mathrm{mg} / \mathrm{kg} /$ day BPA on gestational days 0.5-3.5 can reduce implantation rates to zero by affecting uterine receptivity, embryo transport, and preimplantation embryo development in mice. Berger et al. [25] reported that preimplantation exposure to $200 / 300 \mathrm{mg} / \mathrm{kg} /$ day BPA on gestational days 1-4 can reduce implantation sites by $70 \% / 100 \%$.
Takai et al. [61] showed that, at $100 \mathrm{uM}$, BPA could inhibit the development of preimplantation embryos in vitro. At lower, more environmentally relevant concentrations (1 nM and $3 \mathrm{nM}$ ), BPA has stimulatory effects on embryo development in mice.

4.3. Possible Mechanisms. Uterine receptivity and embryo development are both critical for successful implantation. Coordinated actions of progesterone and estrogen play a critical role in creating a receptive uterine environment, embryo development, and embryo migration through the oviduct $[62,63]$. Estrogen and progesterone actions are critical in the regulation of uterine cell proliferation, establishing a window of receptivity for blastocyst implantation $[64,65]$. In mice, this window is very narrow and sensitive to changes in steroid levels [29, 62]. Small increases in estradiol levels can alter uterine PR (progesterone receptor) and gene expression, causing the uterus to enter a refractory state and thereby decreasing the probability of successful implantation [29]. Kim et al. [66] claimed that, through nuclear ER-dependent ERK1/2 phosphorylation, both E2 and BPA can rapidly and transiently induce Egrl which may be important for embryo implantation and decidualization in mouse uterus. Recently, Mannelli et al. [67] reported that BPA perturbed the expression of $\mathrm{ER} \alpha, \mathrm{ER} \beta, \mathrm{PRA}, \mathrm{PRB}$, and hCG/LH-R, reduced the mRNA transcription of $\mathrm{dPRL}$, and stimulated secretion of MIF in human endometrial stromal cells in vitro.

Several studies have shown that BPA can impair the development of mouse embryos and that this effect can be counteracted by Tamoxifen (an estrogen receptor modulator) $[24,61,68]$. Thus, the impairment of BPA on the embryo is probably mediated by the estrogen receptor.

BPA, TCS, and $17 \beta$-estradiol have similar chemical structures and they are all fat-soluble chemicals. BPA and TCS both have estrogenic activity, share similar pharmacokinetic features, and can be detected in human fluids and tissues. Evidence from clinical studies and animal models supports the assumption that preimplantation exposure to BPA and TCS could lead to implantation failure in humans.

In addition, preimplantation exposure to BPA can nonmonotonically change the expression of the ER $\alpha$ (estrogen receptor $\alpha$ ) and $\mathrm{PR}$ (progesterone receptor) in the uterus of mice [25]. Thus it seems that BPA might interfere with the coordinated actions of progesterone and estrogen and impair the receptivity of the uterus and embryo migration. Xiao et al. [24] reported that preimplantation exposure to BPA affects embryo transport, preimplantation embryo development, and uterine receptivity in mice.

BPA also can increase the luminal area and luminal cell height of the mouse uterus on gestational day 6 following subcutaneous injections of BPA on days 1-4 of gestation [25]. These morphological changes in the uterus could have implications for the success of blastocyst implantation.

Varayoud et al. [69] reported that neonatal exposure to BPA alters rat uterine HOXa10 and its downstream gene expression and reduces the number of implantation sites compared to the control group. Bromer et al. [70] claimed that BPA exposure in utero on gestational days 9-16 (after implantation and in the middle of the pregnancy) can upregulate 


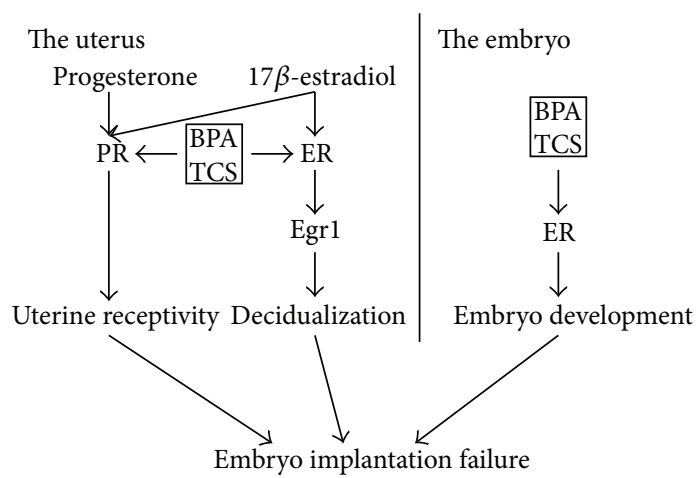

ER: estrogen receptor

PR: progesterone receptor

FIgUre 2: Possible mechanism by which BPA and TCS may affect embryo implantation.

the expression of HOXa10 in the uterus of female offspring in mice. However, whether preimplantation exposure to BPA affects the expression of HOXa10 and its downstream genes has not been investigated.

Some studies have suggested that exposure to BPA could affect the meiotic maturation of oocytes in humans and mice [71-76].

Crawford and deCatanzaro [28] suggested that preimplantation exposure to TCS can also cause implantation failure in mice and that TCS can act in conjunction with BPA. However, the mechanism of this implantation failure in humans and mice is still unknown. The possible mechanism by which the two chemicals may affect embryo implantation is illustrated in Figure 2.

\section{Summary and Suggestions for Further Studies}

In the clinic, fertilization can only be confirmed afterwards. There is no way to detect embryo implantation failure in the clinic except for patients undergoing in vitro fertilization. The most common way to diagnose pregnancy is by testing human chorionic gonadotrophin (HCG) in urine samples. However, HCG is secreted by the syncytiotrophoblast and is detectable in maternal blood two days after the implantation of the embryo [77]. Thus, it is possible that many women did not know that they had a fertilized embryo which failed to implant into their endometrium because no HCG was secreted. Even if there was vaginal bleeding and they went to see a gynecologist, it will only be seen as ovulation bleeding which is very common in the clinic. Most of the time, when a woman wants to know if she is pregnant she will do a urine pregnancy test. However, a detectable level of HCG in the urine requires the embryo to survive for at least a week after implantation. Since BPA and TCS can be absorbed and excreted quickly and do not accumulate in the human body [44, 51-53], a change in habits like starting or stopping using TCS-containing toothpaste or using plastic food containers can cause a fluctuation in the levels of these two chemicals in the human body. This means that if the exposure ceased during the sensitive time frame-for example, the woman has used up her TCS-containing toothpaste and bought some new TCS-free toothpaste or lost her plastic bottles which leak BPA - she could have a relatively low level of TCS and BPA in her body during this time and become pregnant. In the clinic, a woman cannot be defined as infertile unless she has attempted unprotected coitus for at least one year without becoming pregnant. This means that perhaps BPA and TCS have caused more miscarriages than we have realized.

However, the most sensitive time for BPA and TCS to influence implantation remains unknown. Although the preimplantation period might be a sensitive time frame for BPA and TCS exposure, it might not be the most sensitive and important one.

The procedure of in vitro fertilization and embryo transfer (IVF/ET) has provided some possible ways to identify the most dangerous time frame for TCS and BPA exposure in humans. Only in those patients would we know the exact time of fertilization, the condition of the oocyte prefertilization, and the embryo's preimplantation.

Recently, Ehrlich et al. $[15,16]$ studied the association between BPA exposure levels and the clinical outcomes of IVF patients as mentioned above. However, their study did not measure the exposure level of TCS in those patients or the chromosomal condition of the oocytes before fertilization using techniques such as biopsy of their first polar body or the discarded GV (germinal vesicle) oocytes (i.e., immature oocytes). Oocytes with meiotic abnormalities can look normal and even become fertilized, but they lead to a low fertilization rate or a low implantation rate if they are fertilized $[78,79]$.

Many studies have investigated the association between BPA exposure and clinical outcomes in IVF patients [14$16,18]$. However, the menstrual cycles of IVF patients are not natural but are altered using hormones to obtain more ova and the optimal endometrium state during embryo transfer. Since it is likely that BPA and TCS act through estrogen receptors, it is best to study their effect under natural conditions where the status of estrogen receptors and the amount of estrogen in vivo are less affected by exogenous hormones. For example, one could conduct the study in IVF patients undergoing natural cycles. Since only patients with stable menstrual cycles would be included in this procedure, the samples may be more monotonous. Also, most of the animal studies have used the subcutaneous route for exposure $[25,27,28,69]$. However, human exposure to BPA and TCS is mainly orally. So either gavage or food and drink might be a better exposure procedure for animal models.

It is not easy to maintain low TCS and BPA exposure levels due to their widespread existence. And recently it has been reported that BPA-free plastic products also release other chemicals with estrogenic activity [80]. Fortunately, the pharmacokinetic features of these two chemicals suggest that the fertility rate of women could probably be raised just by minimizing contact with BPA- and TCS-containing products during sensitive time frames such as the preimplantation period. However, the other part of reproduction, including the period of the second meiosis of the oocyte, cannot be 
excluded. If we could determine the most sensitive time frame for these two chemicals, we might not need to find a counteractive drug.

\section{Conflict of Interests}

The authors declare that there is no conflict of interests regarding the publication of this paper.

\section{Acknowledgments}

This work was supported by the National Basic Research Program of China (no. 2014CB943300; no. 2012CB944901); the National Natural Science Program of China (no. 81070532; no. 81070541); Natural Science Program of Zhejiang Province, China (no. Y2100822); and Zhejiang Provincial Natural Science Foundation of China (no. LZ13H040001). The authors thank Professor Xu-Feng Huang and Ms. Linda Cohen for their critical reading and proofreading of this review.

\section{References}

[1] H. X. Zhang, S. Y. Wang, S. W. Zhang, T. Wang, and X. H. Deng, "Increasing trend of prevalence of infertility in Beijing," Chinese Medical Journal, vol. 127, no. 4, pp. 691-695, 2014.

[2] R. R. Ramos, G. R. Gutiérrez, I. A. Monroy, and H. G. M. Sánchez, "Risk factors associated to female infertility," Ginecologia y Obstetricia de Mexico, vol. 76, no. 12, pp. 717-721, 2008.

[3] A. Chandra, G. M. Martinez, W. D. Mosher, J. C. Abma, and J. Jones, "Fertility, family planning, and reproductive health of U.S. women: data from the 2002 National Survey of Family Growth," Vital and Health Statistics Series 23, no. 25, pp. 1-160, 2005.

[4] V. C. Wright, J. Chang, G. Jeng, M. Chen, and M. Macaluso, "Assisted reproductive technology surveillance-United States, 2004," MMWR Surveillance Summaries, vol. 56, no. 6, pp. 1-22, 2007.

[5] J. A. Steinkeler, C. A. Woodfield, E. Lazarus, and M. M. Hillstrom, "Female infertility: a systematic approach to radiologic imaging and diagnosis," Radiographics, vol. 29, no. 5, pp. 13531370, 2009.

[6] S. Altmäe, K. Haller, M. Peters et al., "Allelic estrogen receptor 1 (ESR1) gene variants predict the outcome of ovarian stimulation in in vitro fertilization," Molecular Human Reproduction, vol. 13, no. 8, pp. 521-526, 2007.

[7] APME, "An Analysis of European plastics production, demand and waste data," 2014-2015, http://issuu.com/plasticseuropeebook/docs/final_plastics_the_facts_2014_19122.

[8] J. T. Wolstenholme, E. F. Rissman, and J. J. Connelly, “The role of Bisphenol A in shaping the brain, epigenome and behavior," Hormones and Behavior, vol. 59, no. 3, pp. 296-305, 2011.

[9] A. M. Calafat, X. Ye, L.-Y. Wong, J. A. Reidy, and L. L. Needham, "Urinary concentrations of triclosan in the U.S. population: 2003-2004," Environmental Health Perspectives, vol. 116, no. 3, pp. 303-307, 2008.

[10] T. Geens, H. Neels, and A. Covaci, "Distribution of bisphenolA, triclosan and n-nonylphenol in human adipose tissue, liver and brain," Chemosphere, vol. 87, no. 7, pp. 796-802, 2012.
[11] J. M. Braun, K. Yolton, K. N. Dietrich et al., "Prenatal bisphenol A exposure and early childhood behavior," Environmental Health Perspectives, vol. 117, no. 12, pp. 1945-1952, 2009.

[12] D. Caserta, G. Bordi, F. Ciardo et al., "The influence of endocrine disruptors in a selected population of infertile women," Gynecological Endocrinology, vol. 29, no. 5, pp. 444447, 2013.

[13] K. Krishnan, M. Gagné, A. Nong, L. L. Aylward, and S. M. Hays, "Biomonitoring Equivalents for triclosan," Regulatory Toxicology and Pharmacology, vol. 58, no. 1, pp. 10-17, 2010.

[14] V. Y. Fujimoto, D. Kim, F. S. vom Saal, J. D. Lamb, J. A. Taylor, and M. S. Bloom, "Serum unconjugated bisphenol A concentrations in women may adversely influence oocyte quality during in vitro fertilization," Fertility and Sterility, vol. 95, no. 5, pp. 1816-1819, 2011.

[15] S. Ehrlich, P. L. Williams, S. A. Missmer et al., "Urinary bisphenol A concentrations and early reproductive health outcomes among women undergoing IVF,' Human Reproduction, vol. 27, no. 12, pp. 3583-3592, 2012.

[16] S. Ehrlich, P. L. Williams, S. A. Missmer et al., "Urinary bisphenol A concentrations and implantation failure among women undergoing in vitro fertilization," Environmental Health Perspectives, vol. 120, no. 7, pp. 978-983, 2012.

[17] M. Sugiura-Ogasawara, Y. Ozaki, S.-I. Sonta, T. Makino, and K. Suzumori, "Exposure to bisphenol A is associated with recurrent miscarriage," Human Reproduction, vol. 20, no. 8, pp. 2325-2329, 2005.

[18] M. S. Bloom, D. Kim, F. S. vom Saal et al., "Bisphenol A exposure reduces the estradiol response to gonadotropin stimulation during in vitro fertilization," Fertility and Sterility, vol. 96, no. 3, pp. 672.e2-677.e2, 2011.

[19] M. Allmyr, M. Adolfsson-Erici, M. S. McLachlan, and G. Sandborgh-Englund, "Triclosan in plasma and milk from Swedish nursing mothers and their exposure via personal care products," Science of the Total Environment, vol. 372, no. 1, pp. 87-93, 2006.

[20] A. D. Dayan, "Risk assessment of triclosan [Irgasan] in human breast milk," Food and Chemical Toxicology, vol. 45, no. 1, pp. 125-129, 2007.

[21] L. N. Vandenberg, R. Hauser, M. Marcus, N. Olea, and W. V. Welshons, "Human exposure to bisphenol A (BPA)," Reproductive Toxicology, vol. 24, no. 2, pp. 139-177, 2007.

[22] Y. Ikezuki, O. Tsutsumi, Y. Takai, Y. Kamei, and Y. Taketani, "Determination of bisphenol A concentrations in human biological fluids reveals significant early prenatal exposure," Human Reproduction, vol. 17, no. 11, pp. 2839-2841, 2002.

[23] S. P. Krotz, S. A. Carson, C. Tomey, and J. E. Buster, "Phthalates and bisphenol do not accumulate in human follicular fluid," Journal of Assisted Reproduction and Genetics, vol. 29, no. 8, pp. 773-777, 2012.

[24] S. Xiao, H. Diao, M. A. Smith, X. Song, and X. Ye, "Preimplantation exposure to bisphenol A (BPA) affects embryo transport, preimplantation embryo development, and uterine receptivity in mice," Reproductive Toxicology, vol. 32, no. 4, pp. 434-441, 2011.

[25] R. G. Berger, W. G. Foster, and D. deCatanzaro, "BisphenolA exposure during the period of blastocyst implantation alters uterine morphology and perturbs measures of estrogen and progesterone receptor expression in mice," Reproductive Toxicology, vol. 30, no. 3, pp. 393-400, 2010.

[26] R. G. Berger, T. Hancock, and D. deCatanzaro, "Influence of oral and subcutaneous bisphenol-A on intrauterine implantation 
of fertilized ova in inseminated female mice," Reproductive Toxicology, vol. 23, no. 2, pp. 138-144, 2007.

[27] R. G. Berger, J. Shaw, and D. deCatanzaro, "Impact of acute bisphenol-A exposure upon intrauterine implantation of fertilized ova and urinary levels of progesterone and $17 \beta$-estradiol," Reproductive Toxicology, vol. 26, no. 2, pp. 94-99, 2008.

[28] B. R. Crawford and D. deCatanzaro, "Disruption of blastocyst implantation by triclosan in mice: impacts of repeated and acute doses and combination with bisphenol-A," Reproductive Toxicology, vol. 34, no. 4, pp. 607-613, 2012.

[29] W.-G. Ma, H. Song, S. K. Das, B. C. Paria, and S. K. Dey, "Estrogen is a critical determinant that specifies the duration of the window of uterine receptivity for implantation," Proceedings of the National Academy of Sciences of the United States of America, vol. 100, no. 5, pp. 2963-2968, 2003.

[30] A. A. Gidley-Baird, C. O’Neill, M. J. Sinosich, R. N. Porter, I. L. Pike, and D. M. Saunders, "Failure of implantation in human in vitro fertilization and embryo transfer patients: the effects of altered progesterone/estrogen ratios in humans and mice," Fertility and Sterility, vol. 45, no. 1, pp. 69-74, 1986.

[31] E.-M. Jung, B.-S. An, K.-C. Choi, and E.-B. Jeung, "Potential estrogenic activity of triclosan in the uterus of immature rats and rat pituitary GH3 cells," Toxicology Letters, vol. 208, no. 2, pp. 142-148, 2012.

[32] W. V. Welshons, S. C. Nagel, and F. S. vom Saal, "Large effects from small exposures. III. Endocrine mechanisms mediating effects of bisphenol A at levels of human exposure," Endocrinology, vol. 147, no. 6, supplement, pp. S56-S69, 2006.

[33] J. C. Gould, L. Leonard, S. Maness et al., "Bisphenol A interacts with the estrogen receptor alpha in a distinct manner from estradiol," Molecular and Cellular Endocrinology, vol. 142, no. 12, pp. 203-214, 1998.

[34] G. G. J. M. Kuiper, J. G. Lemmen, B. Carlsson et al., "Interaction of estrogenic chemicals and phytoestrogens with estrogen receptor $\beta$," Endocrinology, vol. 139, no. 10, pp. 4252-4263, 1998.

[35] W. D. Pennie, T. C. Aldridge, and A. N. Brooks, "Differential activation by xenoestrogens of $\operatorname{ER} \alpha$ and $\operatorname{ER} \beta$ when linked to different response elements," Journal of Endocrinology, vol. 158, no. 3, pp. R11-R14, 1998.

[36] H.-R. Lee, K.-A. Hwang, K.-H. Nam, H.-C. Kim, and K.-C. Choi, "Progression of breast cancer cells was enhanced by endocrine-disrupting chemicals, triclosan and octylphenol, via an estrogen receptor-dependent signaling pathway in cellular and mouse xenograft models," Chemical Research in Toxicology, vol. 27, no. 5, pp. 834-842, 2014.

[37] S. Miyagawa, A. Lange, I. Hirakawa et al., "Differing species responsiveness of estrogenic contaminants in fish is conferred by the ligand binding domain of the estrogen receptor," Environmental Science and Technology, vol. 48, no. 9, pp. 5254-5263, 2014.

[38] X. Xu, Y. Lu, G. Zhang et al., "Bisphenol A promotes dendritic morphogenesis of hippocampal neurons through estrogen receptor-mediated ERK1/2 signal pathway," Chemosphere, vol. 96, pp. 129-137, 2014.

[39] S. M. Kim, E. M. Jung, B. S. An et al., "Additional effects of bisphenol A and paraben on the induction of calbindin-D9K and progesterone receptor via an estrogen receptor pathway in rat pituitary GH3 cells," Journal of Physiology and Pharmacology, vol. 63, no. 5, pp. 445-455, 2012.

[40] A. Rivas, M. Lacroix, F. Olea-Serrano, I. Laos, G. Leclercq, and N. Olea, "Estrogenic effect of a series of bisphenol analogues on gene and protein expression in MCF-7 breast cancer cells," The Journal of Steroid Biochemistry and Molecular Biology, vol. 82, no. 1, pp. 45-53, 2002.

[41] T. E. Stoker, E. K. Gibson, and L. M. Zorrilla, “Triclosan exposure modulates estrogen-dependent responses in the female wistar rat," Toxicological Sciences, vol. 117, no. 1, pp. 45-53, 2010.

[42] H. Ishibashi, N. Matsumura, M. Hirano et al., "Effects of triclosan on the early life stages and reproduction of medaka Oryzias latipes and induction of hepatic vitellogenin," Aquatic Toxicology, vol. 67, no. 2, pp. 167-179, 2004.

[43] W. Dekant and W. Völkel, "Human exposure to bisphenol A by biomonitoring: methods, results and assessment of environmental exposures," Toxicology and Applied Pharmacology, vol. 228, no. 1, pp. 114-134, 2008.

[44] J. A. Taylor, F. S. vom Saal, W. V. Welshons et al., "Similarity of bisphenol A pharmacokinetics in rhesus monkeys and mice: relevance for human exposure," Environmental Health Perspectives, vol. 119, no. 4, pp. 422-430, 2011.

[45] T. H. Lassen, H. Frederiksen, T. K. Jensen et al., “Temporal variability in urinary excretion of bisphenol A and seven other phenols in spot, morning, and 24-h urine samples," Environmental Research, vol. 126, pp. 164-170, 2013.

[46] T. Geens, L. Roosens, H. Neels, and A. Covaci, "Assessment of human exposure to Bisphenol-A, Triclosan and Tetrabromobisphenol-A through indoor dust intake in Belgium," Chemosphere, vol. 76, no. 6, pp. 755-760, 2009.

[47] M. K. Morgan, P. A. Jones, A. M. Calafat et al., "Assessing the quantitative relationships between preschool children's exposures to bisphenol a by route and urinary biomonitoring," Environmental Science and Technology, vol. 45, no. 12, pp. 53095316, 2011.

[48] N. K. Wilson, J. C. Chuang, M. K. Morgan, R. A. Lordo, and L. S. Sheldon, "An observational study of the potential exposures of preschool children to pentachlorophenol, bisphenol-A, and nonylphenol at home and daycare," Environmental Research, vol. 103, no. 1, pp. 9-20, 2007.

[49] J. G. Teeguarden and S. Hanson-Drury, "A systematic review of Bisphenol A 'low dose' studies in the context of human exposure: a case for establishing standards for reporting 'lowdose' effects of chemicals," Food and Chemical Toxicology, vol. 62, pp. 935-948, 2013.

[50] M. Allmyr, F. Harden, L.-M. L. Toms et al., “The influence of age and gender on triclosan concentrations in Australian human blood serum," Science of the Total Environment, vol. 393, no. 1, pp. 162-167, 2008.

[51] J. V. Rodricks, J. A. Swenberg, J. F. Borzelleca, R. R. Maronpot, and A. M. Shipp, "Triclosan: a critical review of the experimental data and development of margins of safety for consumer products," Critical Reviews in Toxicology, vol. 40, no. 5, pp. 422484, 2010.

[52] W. Völkel, T. Colnot, G. A. Csanády, J. G. Filser, and W. Dekant, "Metabolism and kinetics of bisphenol a in humans at low doses following oral administration," Chemical Research in Toxicology, vol. 15, no. 10, pp. 1281-1287, 2002.

[53] W. V. Völkel, N. Bittner, and W. Dekant, "Quantitation of bisphenol A and bisphenol A glucuronide in biological samples by high performance liquid chromatography-tandem mass spectrometry," Drug Metabolism and Disposition, vol. 33, no. 11, pp. 1748-1757, 2005.

[54] G. Sandborgh-Englund, M. Adolfsson-Erici, G. Odham, and J. Ekstrand, "Pharmacokinetics of triclosan following oral 
ingestion in humans," Journal of Toxicology and Environmental Health Part A: Current Issues, vol. 69, no. 20, pp. 1861-1873, 2006.

[55] D. M. Bagley and Y. I.-J. Lin, "Clinical evidence for the lack of triclosan accumulation from daily use in dentifrices," American Journal of Dentistry, vol. 13, no. 3, pp. 148-152, 2000.

[56] Y.-J. Lin, "Buccal absorption of triclosan following topical mouthrinse application," The American Journal of Dentistry, vol. 13, no. 4, pp. 215-217, 2000.

[57] L.-Q. Wang, C. N. Falany, and M. O. James, “Triclosan as a substrate and inhibitor of $3^{\prime}$ - phosphoadenosine $5^{\prime}$-phosphosulfatesulfotransferase and UDP-glucuronosyl transferase in human liver fractions," Drug Metabolism and Disposition, vol. 32, no. 10, pp. 1162-1169, 2004.

[58] T. Steck, R. Giess, M. W. Suetterlin et al., "Leukaemia inhibitory factor (LIF) gene mutations in women with unexplained infertility and recurrent failure of implantation after IVF and embryo transfer," European Journal of Obstetrics Gynecology and Reproductive Biology, vol. 112, no. 1, pp. 69-73, 2004.

[59] R. G. Edwards, "Implantation, interception and contraception," Human Reproduction, vol. 9, no. 6, pp. 985-995, 1994.

[60] C. Simón, C. Moreno, J. Remohí, and A. Pellicer, "Cytokines and embryo implantation," Journal of Reproductive Immunology, vol. 39, no. 1-2, pp. 117-131, 1998.

[61] Y. Takai, O. Tsutsumi, Y. Ikezuki et al., "Estrogen receptormediated effects of a xenoestrogen, bisphenol A, on preimplantation mouse embryos," Biochemical and Biophysical Research Communications, vol. 270, no. 3, pp. 918-921, 2000.

[62] B. C. Paria, Y. M. Huet-Hudson, and S. K. Dey, "Blastocyst's state of activity determines the 'window' of implantation in the receptive mouse uterus," Proceedings of the National Academy of Sciences of the United States of America, vol. 90, no. 21, pp. 10159-10162, 1993.

[63] L. S. Roblero and A. C. Garavagno, "Effect of oestradiol-17 beta and progesterone on oviductal transport and early development of mouse embryos," Journal of Reproduction and Fertility, vol. 57, no. 1, pp. 91-95, 1979.

[64] Y. M. Huet-Hudson, G. K. Andrews, and S. K. Dey, "Cell typespecific localization of c-myc protein in the mouse uterus: modulation by steroid hormones and analysis of the periimplantation period," Endocrinology, vol. 125, no. 3, pp. 1683-1690, 1989.

[65] S. W. Potter, G. Gaza, and J. E. Morris, "Estradiol induces E-cadherin degradation in mouse uterine epithelium during the estrous cycle and early pregnancy," Journal of Cellular Physiology, vol. 169, no. 1, pp. 1-14, 1996.

[66] H.-R. Kim, Y. S. Kim, J. A. Yoon et al., "Egrl is rapidly and transiently induced by estrogen and bisphenol A via activation of nuclear estrogen receptor-dependent ERK1/2 pathway in the uterus," Reproductive Toxicology, vol. 50, pp. 60-67, 2014.

[67] C. Mannelli, A. Z. Szostek, K. Lukasik et al., "BisphenolA modulates receptivity and secretory function of human decidual cells: an in vitro study," Reproduction, 2015.

[68] Y. Takai, O. Tsutsumi, Y. Ikezuki et al., "Preimplantation exposure to bisphenol A advances postnatal development," Reproductive Toxicology, vol. 15, no. 1, pp. 71-74, 2001.

[69] J. Varayoud, J. G. Ramos, V. L. Bosquiazzo, M. Lower, M. Muñoz-de-Toro, and E. H. Luque, "Neonatal exposure to bisphenol A alters rat uterine implantation-associated gene expression and reduces the number of implantation sites," Endocrinology, vol. 152, no. 3, pp. 1101-1111, 2011.
[70] J. G. Bromer, Y. Zhou, M. B. Taylor, L. Doherty, and H. S. Taylor, "Bisphenol-A exposure in utero leads to epigenetic alterations in the developmental programming of uterine estrogen response," The FASEB Journal, vol. 24, no. 7, pp. 2273-2280, 2010.

[71] A. Can, O. Semiz, and O. Cinar, "Bisphenol-A induces cell cycle delay and alters centrosome and spindle microtubular organization in oocytes during meiosis," Molecular Human Reproduction, vol. 11, no. 6, pp. 389-396, 2005.

[72] P. A. Hunt, K. E. Koehler, M. Susiarjo et al., "Bisphenol a exposure causes meiotic aneuploidy in the female mouse," Current Biology, vol. 13, no. 7, pp. 546-553, 2003.

[73] M. Susiarjo, T. J. Hassold, E. Freeman, and P. A. Hunt, "Bisphenol A exposure in utero disrupts early oogenesis in the mouse," PLoS Genetics, vol. 3, no. 1, article e5, 2007.

[74] R. Machtinger, C. M. H. Combelles, S. A. Missmer et al., "Bisphenol-A and human oocyte maturation in vitro," Human Reproduction, vol. 28, no. 10, pp. 2735-2745, 2013.

[75] S. Lenie, R. Cortvrindt, U. Eichenlaub-Ritter, and J. Smitz, "Continuous exposure to bisphenol A during in vitro follicular development induces meiotic abnormalities," Mutation Research-Genetic Toxicology and Environmental Mutagenesis, vol. 651, no. 1-2, pp. 71-81, 2008.

[76] U. Eichenlaub-Ritter, E. Vogt, S. Cukurcam, F. Sun, F. Pacchierotti, and J. Parry, "Exposure of mouse oocytes to bisphenol A causes meiotic arrest but not aneuploidy," Mutation Research/Genetic Toxicology and Environmental Mutagenesis, vol. 651, no. 1-2, pp. 82-92, 2008.

[77] T. Fournier, J. Guibourdenche, and D. Evain-Brion, "Review: hCGs: different sources of production, different glycoforms and functions," Placenta, vol. 36, pp. S60-S65, 2015.

[78] S. Munné, "Chromosome abnormalities and their relationship to morphology and development of human embryos," Reproductive BioMedicine Online, vol. 12, no. 2, pp. 234-253, 2006.

[79] A. Kuliev, J. Cieslak, Y. Ilkevitch, and Y. Verlinsky, "Chromosomal abnormalities in a series of 6733 human oocytes in preimplantation diagnosis for age-related aneuploidies," Reproductive BioMedicine Online, vol. 6, no. 1, pp. 54-59, 2003.

[80] G. D. Bittner, C. Z. Yang, and M. A. Stoner, "Estrogenic chemicals often leach from BPA-free plastic products that are replacements for BPA-containing polycarbonate products," Environmental Health, vol. 13, no. 1, article 41, 2014.

[81] T. Takeuchi and O. Tsutsumi, "Serum bisphenol a concentrations showed gender differences, possibly linked to androgen levels," Biochemical and Biophysical Research Communications, vol. 291, no. 1, pp. 76-78, 2002.

[82] Y. Sun, M. Irie, N. Kishikawa, M. Wada, N. Kuroda, and K. Nakashima, "Determination of bisphenol A in human breast milk by HPLC with column-switching and fluorescence detection," Biomedical Chromatography, vol. 18, no. 8, pp. 501-507, 2004.

[83] R. Kuruto-Niwa, Y. Tateoka, Y. Usuki, and R. Nozawa, "Measurement of bisphenol A concentrations in human colostrum," Chemosphere, vol. 66, no. 6, pp. 1160-1164, 2007.

[84] X. Li, G.-G. Ying, J.-L. Zhao, Z.-F. Chen, H.-J. Lai, and H.-C. $\mathrm{Su}$, "4-Nonylphenol, bisphenol-A and triclosan levels in human urine of children and students in China, and the effects of drinking these bottled materials on the levels," Environment International, vol. 52, pp. 81-86, 2013.

[85] E. J. Kim, D. Lee, B. C. Chung, H. Pyo, and J. Lee, "Association between urinary levels of bisphenol-A and estrogen metabolism in Korean adults," Science of the Total Environment, vol. 470-471, pp. 1401-1407, 2014. 
[86] M. F. Fernandez, J. P. Arrebola, J. Taoufiki et al., "BisphenolA and chlorinated derivatives in adipose tissue of women," Reproductive Toxicology, vol. 24, no. 2, pp. 259-264, 2007.

[87] L.-M. L. Toms, M. Allmyr, J. F. Mueller et al., "Triclosan in individual human milk samples from Australia," Chemosphere, vol. 85, no. 11, pp. 1682-1686, 2011. 


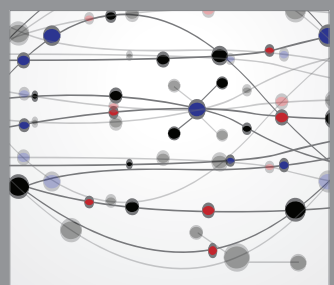

The Scientific World Journal
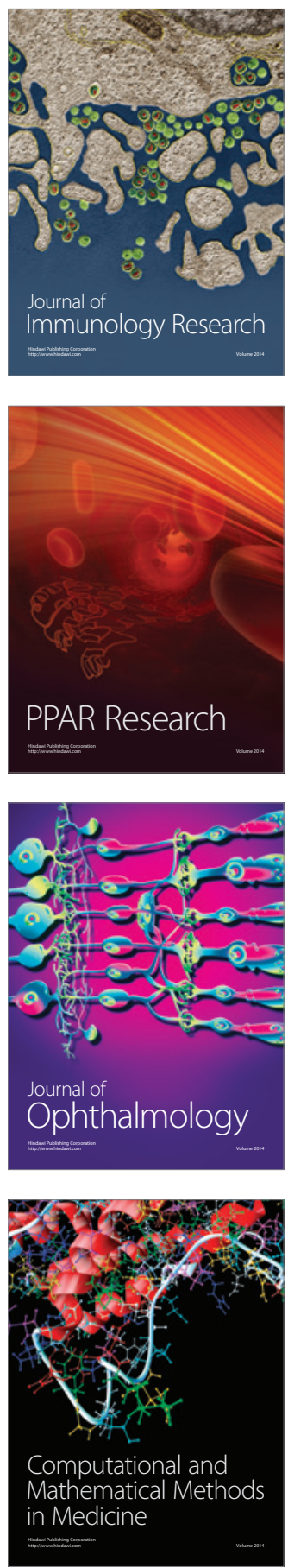

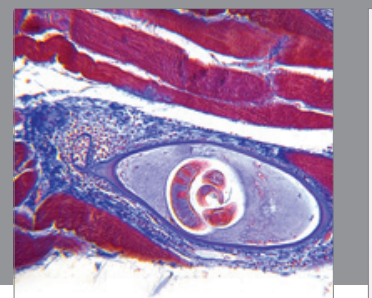

Gastroenterology

Research and Practice
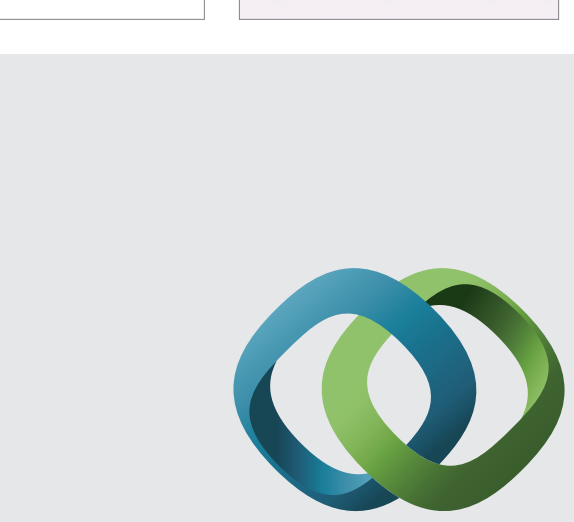

\section{Hindawi}

Submit your manuscripts at

http://www.hindawi.com
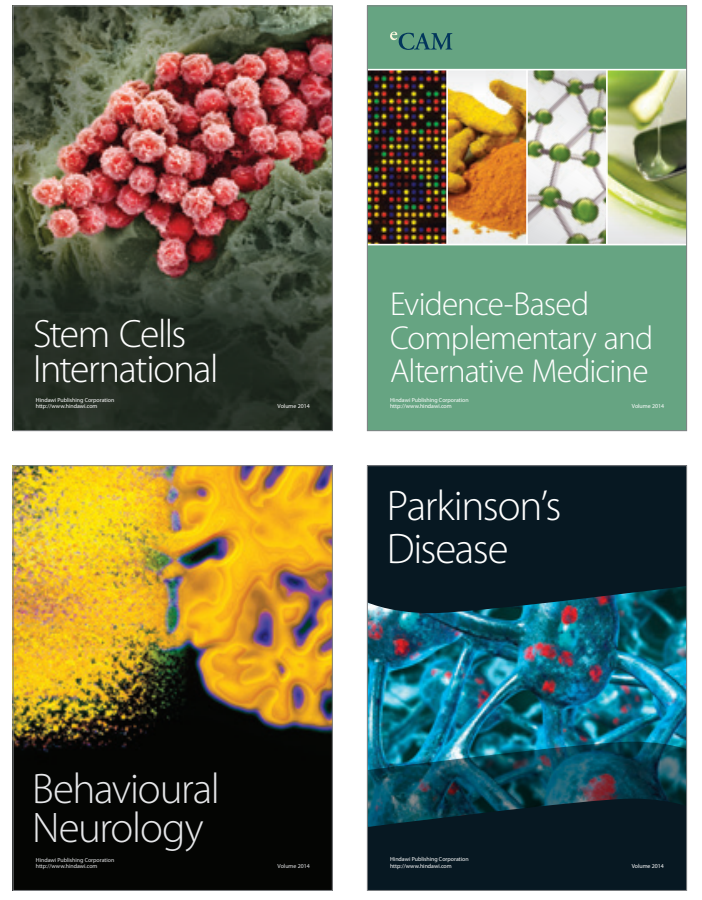
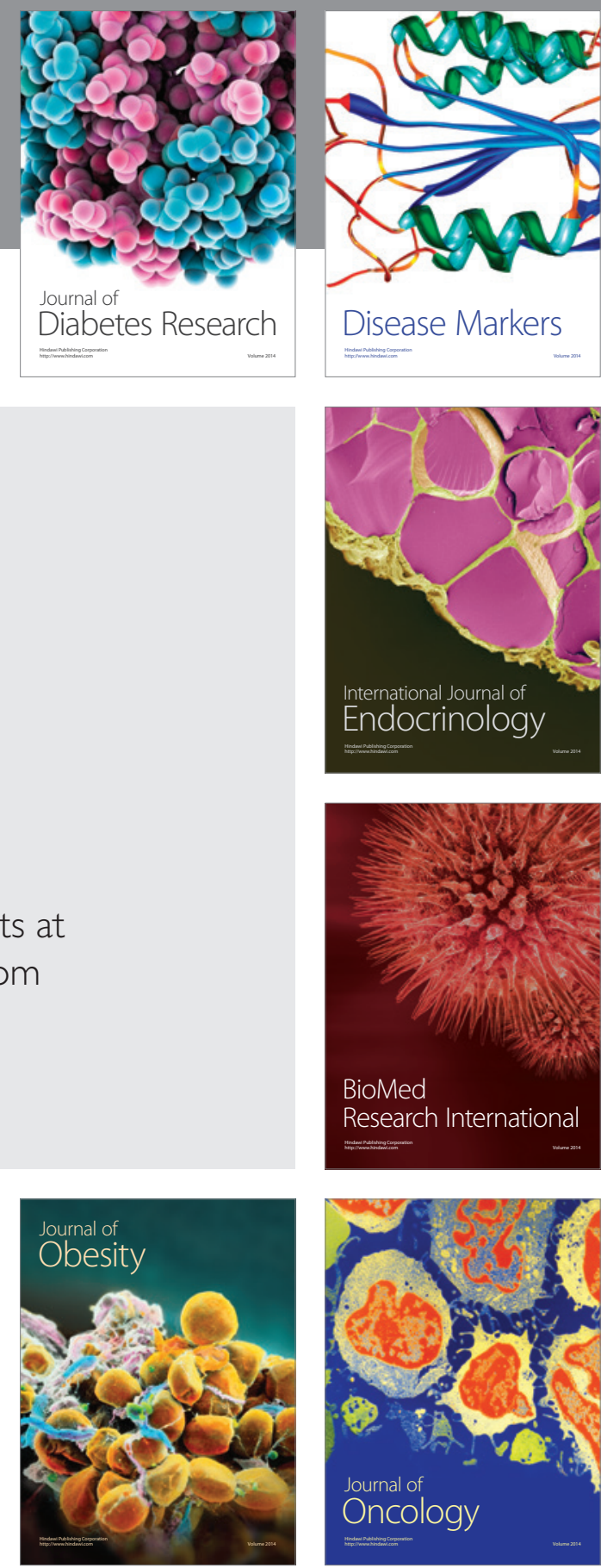

Disease Markers
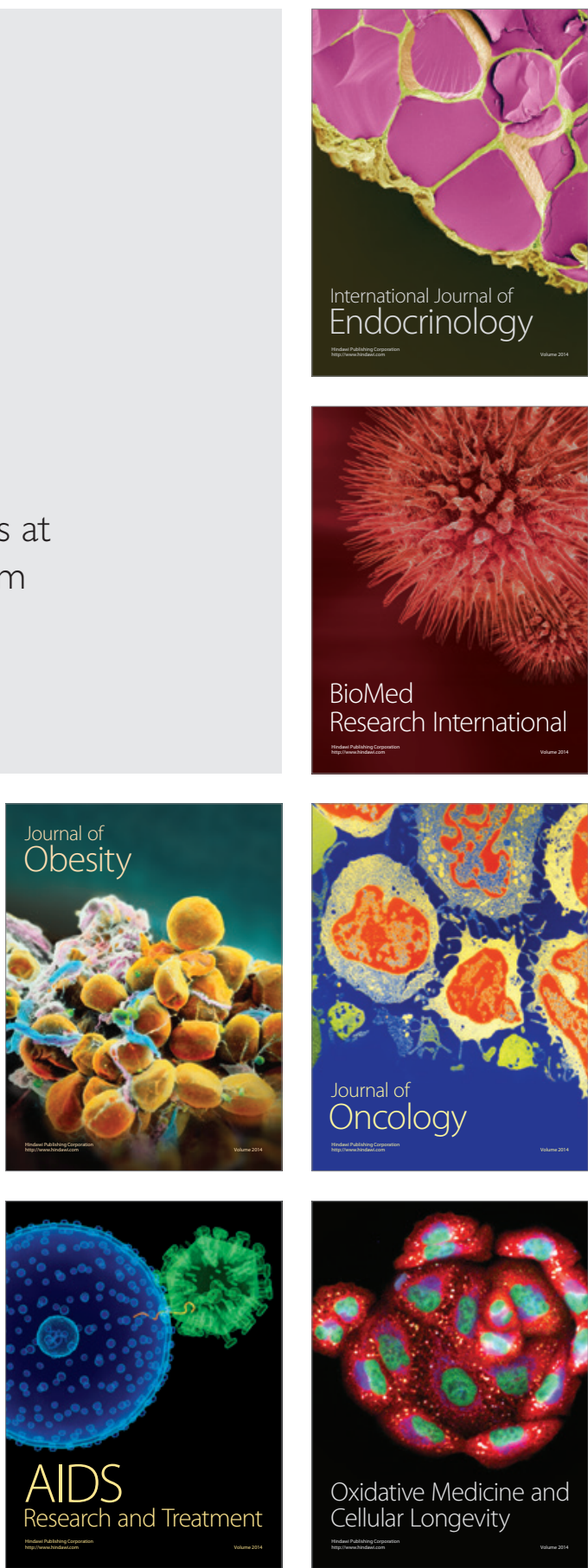